\title{
$\mathrm{RA}$ 病変により第 1 腰椎破壊をきたした \\ 1 手術症例の検討
}

\begin{tabular}{|c|c|c|c|c|c|}
\hline 浪 & 花 & 紳 & 悟・上 & 平 & \\
\hline 大 & 月 & 健 & 二・森 & 尾 & 泰 \\
\hline 林 & & 寛 & - & & \\
\hline
\end{tabular}

\section{Progressive Destruction of the Ist Lumbar Vertebral Body Caused by Rheumatoid Involvement: A Case Report}

by

\author{
Shingo Naniwa, Motiru Kamihira, Kenji Ohtsuki, \\ Yasuo Morio and Kanichi Hayashi
}

Department of Orthopedic Surgery, Misasa Onsen National Hospital

\begin{abstract}
We reported a sixty-year-old woman with rheumatoid arthritis in whom involvement of the Ist lumbar vertebra occurred. She had a history of seropositive rheumatoid arthritis for 24 years. Low back pain attacked her and it increased gradually, and she felt too painful to sit on bed for few minutes. Radiograph showed a progressive destructive lesion in $\mathrm{L}_{1}$ and myelography did almost complete obstruction at the $\mathrm{L}_{1}$ level. An anterior decompression with interbody fusion from $\mathrm{Th}_{12}$ to $\mathrm{L}_{2}$ was performed. At operation, granulation tissue was found in $\mathrm{L}_{1}$ body and histological examination of it showed chronic non-specific granulomatous inflammation.

Five months after operation, low back pain had settled and she was able to sit on bed easily.
\end{abstract}

\section{は じめに}

慢性関節リウマチ $(R A)$ 患者における脊椎病変のな かで，䅡椎の報告は多く見られるが，胸腰椎に関して は比較的少い. 今回われわれは RA で第 1 腰椎 $\left(L_{1}\right)$ の椎体破壊をきたした症例を経験し観血的治療を施行 したので報告する。

症

例

症例：60 才，女性。

classical RA, stage IV, class IV

主訴: 腰痛, 両下腿のシビレ感, 膀胱直腸障害

現病歴：昭和 37 年両膝関節痛にて発症, 昭和 59 年 8 月よりステロイド内服開始. 同年両膝 TKR 施行. 昭 和 60 年 3 月 22 日, 発熱・咳漱あり肺炎の診断にて当 院内科入院, 入院して数日後, 咳漱と伴に腰痛出現.
レ線上 $\mathrm{L}_{1}$ 圧迫骨折を認めた。 60 年 9 月頃より右下腿外 側のシビレ感出現，以後徐々にシビレ領域増大した。 61 年 1 月頃より排尿困難出現，この頃まではなんとか 歩行器による独歩可能であったが, 腰痛・両殿部痛の ため坐位も不能でねたきりとなり, 安静時腰痛もあっ た。保存的治療続けるも症状軽快せず， 61 年 5 月当科 転科となった。

既往歴・家族歴：特記すべきことなし。

転科時所見：身長 $151.5 \mathrm{~cm}$, 体重 $40 \mathrm{~kg}$ 両上下肢の 多関節に変形を認める. 上肢の腱反射正常, 知覚障害 なし, 坐位は腰痛, 両殿部痛のため保持不能, 体位変 換困難, $\mathrm{L}_{1}$ を頂点とする亀背あり, $\mathrm{L}_{1}$ 圧痛あり, FNST 両側陽性, PTR 正常, ATR は足関節の拘縮のため判 定不能, 病的反射なく, 両下肢膝以下に知覚低下あり. 膀胱直腸障害を認める.

血液・生化学検查 (表 1$): \mathrm{RA}(+), \mathrm{CRP}(+)$, 血 
沈六進というリウマチ反応陽性以外著変なし。

X線所見：腰椎の経時的変化を示寸.昭和 59 年 9 月 のレ線では骨萎縮を認めるのみ, 矢印で示す $L_{1}$ 圧迫骨 折は認めず。腰痛の出現した昭和 60 年 3 月に圧迫骨折 出現し, その 2 力月後には骨破壊像を認め, 以後骨破 壞は進行し,腰痛出現より 1 年後の昭和 61 年 2 月には 椎体はほとんど消失し, 残存椎体を含めて後方へすべ っている(図 1 ).

術前（腰痛発症より 1 年 3 力月後）には椎体破壊,

表 1 臨床検査所見

\begin{tabular}{|c|c|c|c|}
\hline 赤血球数 & 345万 & Al-P & $71 \mathrm{IU}$ \\
\hline ヘモグロビン & $11.1 \mathrm{~g} / \mathrm{dl}$ & 尿酸值 & $5.6 \mathrm{mg} / \mathrm{dl}$ \\
\hline ヘマトクリット & $33.5 \%$ & クレアチニン & $0.6 \mathrm{mg} / \mathrm{dl}$ \\
\hline 白血球数 & 5,300 & BUN & $16 \mathrm{mg} / \mathrm{dl}$ \\
\hline 総蛋白 & $6.6 \mathrm{~g} / \mathrm{dl}$ & 赤沈值 & 90/1時間 \\
\hline A／G比 & 0.64 & $\begin{array}{l}\text { CRP } \\
\text { シアル酸 }\end{array}$ & $\stackrel{+}{{ }_{8}} \cdot \mathrm{mg} / \mathrm{dl}$ \\
\hline Al. & $39.2 \%$ & RA & + \\
\hline$\alpha_{1} \mathrm{Gl}$ & $5.1 \%$ & $\mathrm{RA}-\mathrm{HA}$ & $1280 \times$ \\
\hline$\alpha_{2}$ Gl. & $10.0 \%$ & 尿蛋白 & $(-)$ \\
\hline$\beta \mathrm{Gl}$. & $8.0 \%$ & ベンスジョーンズ & \\
\hline$\gamma \mathrm{Gl}$. & $37.7 \%$ & 蛋白体 & $(-)$ \\
\hline GOT & $56 \mathrm{IU}$ & ツ反 & $(-)$ \\
\hline GPT & 81IU & & \\
\hline
\end{tabular}
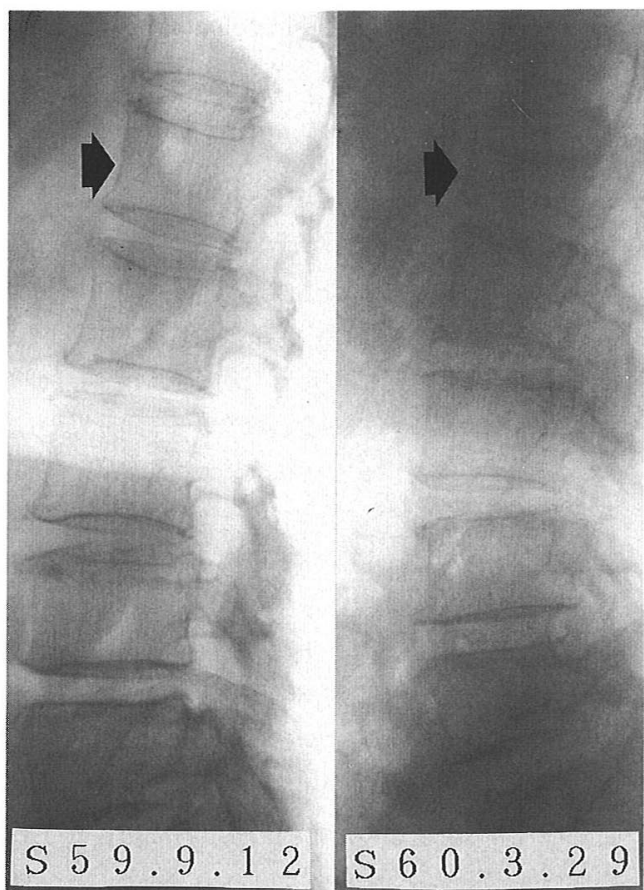

すべりともさらに進行しているが，正面像において回 旋脱臼は認めない（図 2 )。

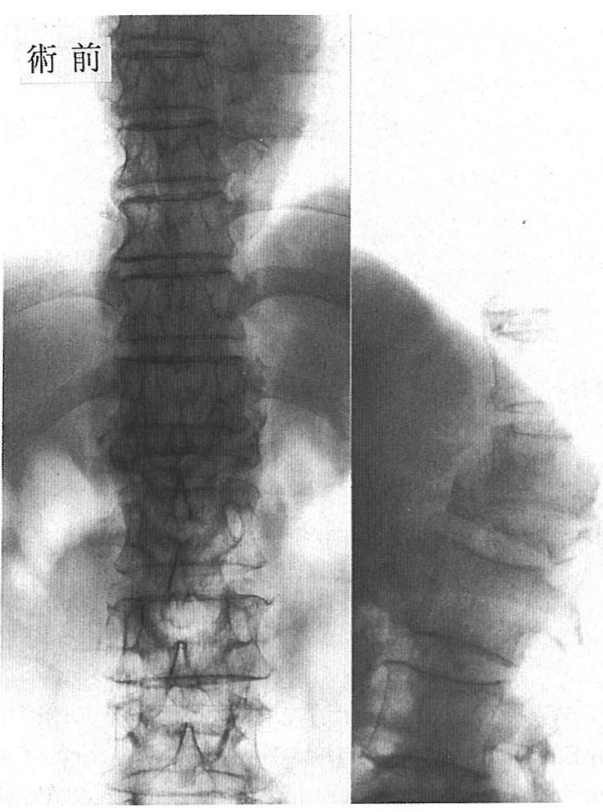

図 2 術前単純レ線 $\mathrm{L}_{1}$ の破壊と後方すべりが見られる。

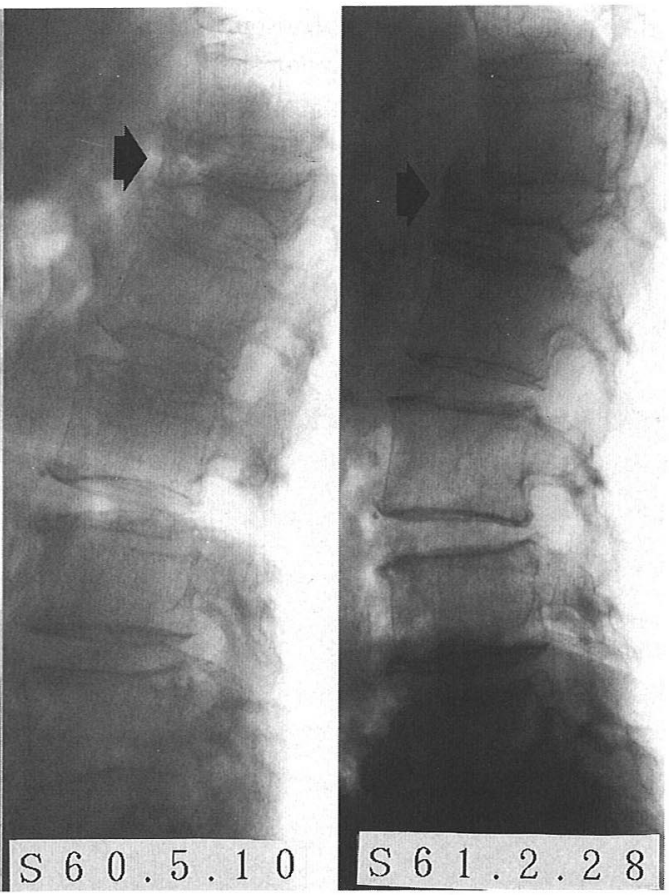

S 61.2 .28

図 1 経時的単純レ線 徐々に椎体破壊が進行している。(矢印は $\mathrm{L}_{1}$ 椎体を示す) 


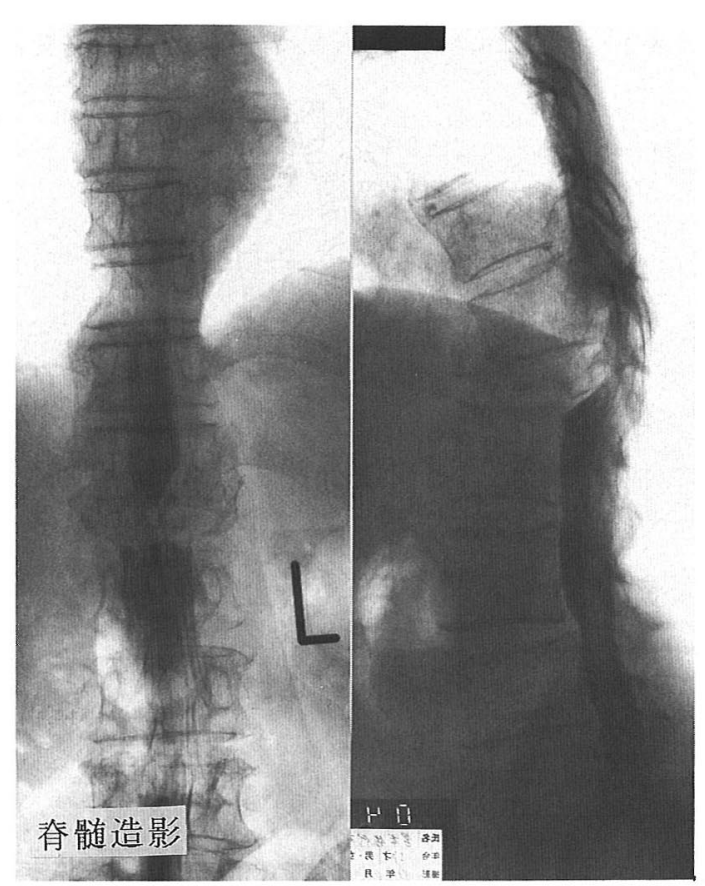

図 3

$\mathrm{L}_{1}$ レベルでの完全ブロックを呈す。

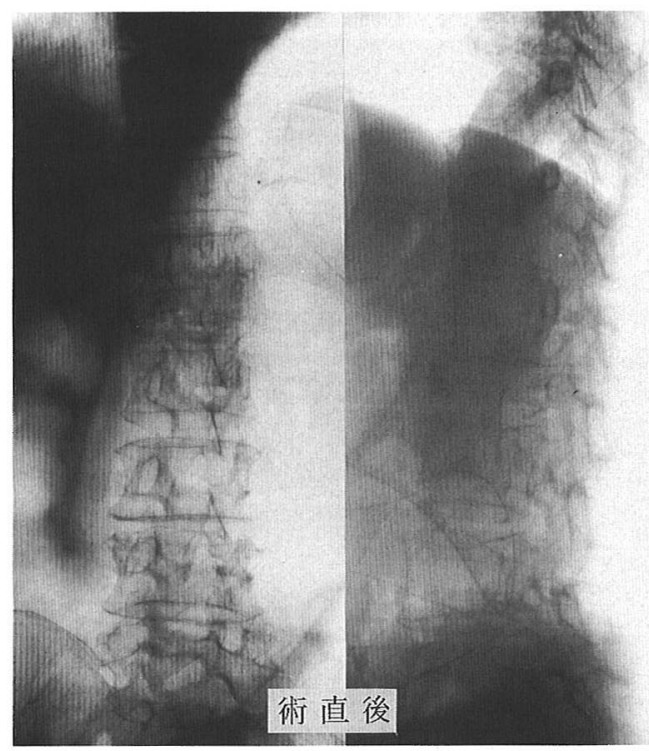

図 4 施行後のレ線

$\mathrm{L}_{1}$ 椎体亜全摘ならびに前方固定術施行後の L 線像

脊髄造影では $\mathrm{L}_{1}$ におけるほぼ完全ブロック像を呈し (図 3 ), 同時に施行したCTM でも椎体による前方か

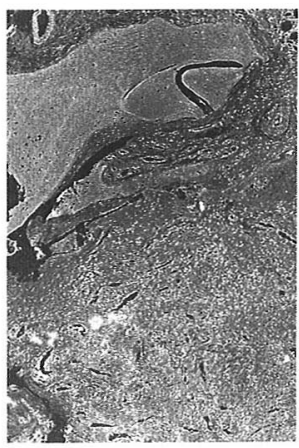

$(\times 40)$

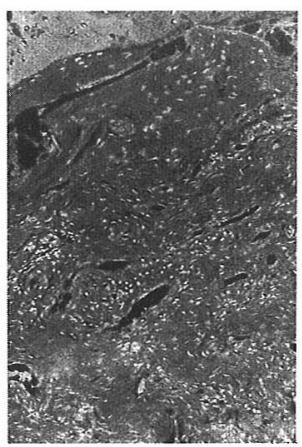

$(\times 100)$
図 5 病理組織像

fibrinous infiltration と毛細血管の増生を認める。

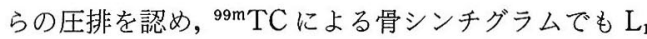
に著明な異常集積像は認めなかった。

経過ならびに手術所見：症状の軽快なく, 骨髄腫, 骨転移などの除外診断の後，リウマチによる病変と考 え, 昭和 61 年 6 月 23 日, 経左第 10 助骨, 胸膜外, 腹 膜外進入による $\mathrm{L}_{1}$ 椎体亜全摘ならびに腸骨, 摘出胁骨 による椎体固定術を施行した（図 4).

術中 $\mathrm{L}_{1}$ 椎体上下の椎間板は変性あるもほぼ正常, $\mathrm{L}_{1}$ 椎体上縁の終板は紙のごとく薄くなっていた. $\mathrm{L}_{1}$ 椎体 骨髄内に扊白色, 弾性軟の肉芽様組織を認めた。

術後 5 力月の現在, $\mathrm{Th}_{12} \cdot \mathrm{L}_{2}$ 間の狭小化と不安定性を 示し, 整復状態は必らずしも満足すべきではないが, 腰痛はまったく消失, 坐位は容易となり一応手術の目 的は達したと考えている。

病理組織学的所見 $: L_{1}$ 椎体骨髄内の肉芽様組織は, 典型的なりウマチ結節の像は呈しないが, fibrinous infiltration と毛細血管の増生という慢性肉芽性炎症の 像であった (図 5 )。。なお隣接する椎間板は, 変性像あ るも肉芽の浸潤はみていない。

考察

RA 患者の胸腰椎病変に関して Baggenstoss ${ }^{1)}$, 七 $川^{5)}$ ，菅野(6)，桑原 ${ }^{4)}$ ，Heywood ら ${ }^{3)}$ の報告があるが， われわれは過去 5 年間当科にて RA の診断にて入院し た 220 名のなかより胸腰椎レ線のある患者(胸椎 24 例, 腰椎 65 例) のレ線を検討し, 表 2 -Aに示す所見を得 た.七川の言う RAに特徵的とする椎体の侵蝕像は本 症例の 1 例のみで,他は O. A. あるいは骨粗鬆症による 変化を多くみた。しかし椎間板狭少化を示す症例のな 
かに椎間板に接する椎体辺緑がやや不整な症例が数例 あり， RA を含むなんらかの炎症の存在を疑わせた。

また, RA 患者における圧迫骨折は 22 症例 23 椎体に 認め病巣レベルは表 $2-B$ に示すごとく，通常の圧迫 骨折のおこりやすい胸腰椎移行部に多く, $\mathrm{Th}_{11}, \mathrm{Th}_{12}$, $\mathrm{L}_{1}$ の 3 椎体で全体の約半数を占める. RA 患者の胸腰 椎移行部の圧迫骨折 3 症例のレ線像（図 6 ）を本症例 と比較すると，圧迫の程度は種々であるが上下の椎間 板は保たれ，椎体辺緑はしっかりしており，椎体内の 陰影も均一な感じを与え, レ線上からも通常の圧迫骨

表 2-A 当院における過去 5 年間の $\mathrm{R} A$ 入院患者の胸腰 椎レ線所見

\begin{tabular}{|c|c|c|c|c|c|}
\hline & $\begin{array}{l}\text { 椎体の } \\
\text { 浸蝕像 }\end{array}$ & $\begin{array}{l}\text { 骨棘を伴 } \\
\text { わない椎 } \\
\text { 間板狭小 } \\
\text { 化 }\end{array}$ & $\begin{array}{l}\text { 骨棘あるい } \\
\text { は硬化像を } \\
\text { 伴う椎間板 } \\
\text { 狭小化 }\end{array}$ & $\begin{array}{l}\text { 椎間板前 } \\
\text { 方の骨化 } \\
\text { あるいは } \\
\text { 石灰化 }\end{array}$ & $\begin{array}{l}\text { 圧迫 } \\
\text { 骨折 }\end{array}$ \\
\hline $\begin{array}{c}\text { 胸椎 } \\
\text { (24例) }\end{array}$ & 0 & 0 & 2 & 0 & 14 \\
\hline $\begin{array}{c}\text { 腰椎 } \\
\text { (65例) }\end{array}$ & 1 & 4 & 14 & 2 & 8 \\
\hline
\end{tabular}

(七川, Heywoodの分類による)

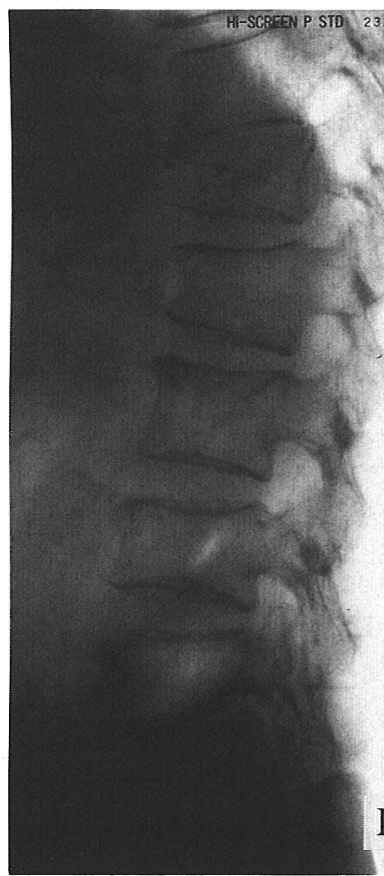

R A 患者の压迫骨折（3症例）
表 2-B 当院におけるRA患者の椎体別压迫骨折数

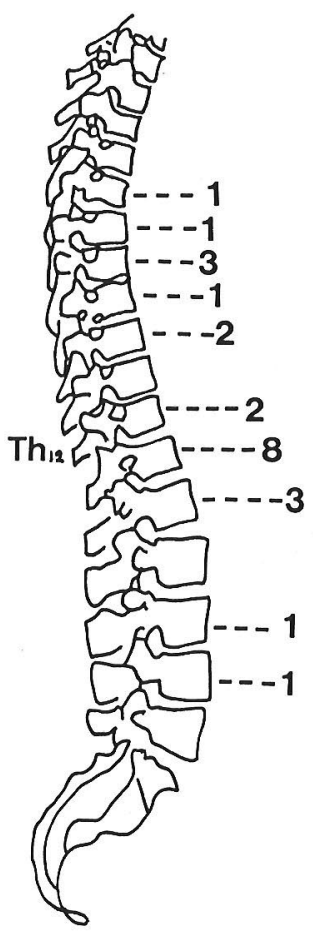

ThP

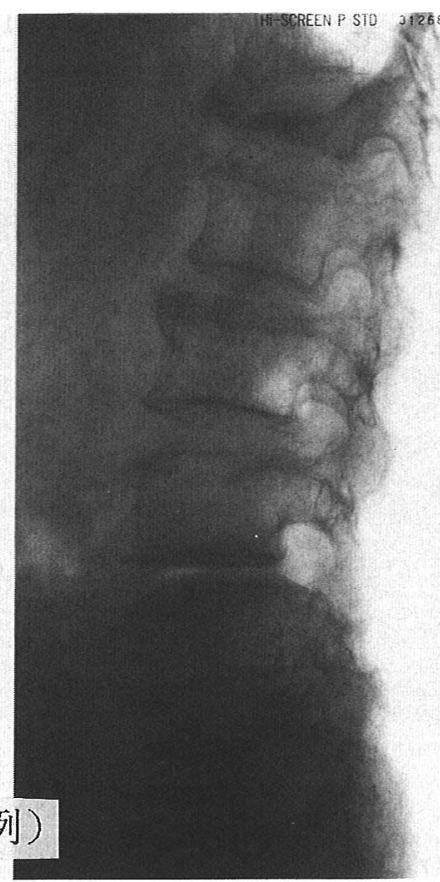

図 6 本症例と比較すると，上下の椎間板は保たれ椎体辺縁ははっきりしており，椎体内の陰影も均一である。 
腫，癌の骨転移，骨粗鬆症，その他結核を始めとする 特異性炎症などがあげられるが，本症例ではベンスジ ョーンズ蛋白体陰性, 他にレ線上 punched out lesion 認めず, 臨床上骨転移を思わせる重とくな myelopathy を示さず，骨シンチグラムにても高集積像なく，ツ反 陰性, 抗生剂使用するも軽快せず, 術中摘出骨髄組織 の培養陰性などの臨床所見と, 組織学的にもこれらの 特異所見を認めなかったことより鑑別可能である.

胸腰椎における RA 病変の存在部位については, 滑 膜関節である椎間関節, 前 - 後縦勒帯と椎間板, 椎体 が接する entheso-peridiscal region，あるいは椎体内 の病変があるが, 本症例は, レ線上椎体後方要素は比 較的温存され, 椎間板は正常, 椎体に肉芽組織を認め, 組織学的にリウマチ結節は証明出来なかったが，慢性 肉芽性炎症の診断により，椎体内のリウマチ病変によ るものと考えている.

治療に関しては, 胸腰椎のリウマチ病変に対する観 血的治療の報告はさらに少いが，骨破壊が進行性で高 度となり, 保存的治療に抵抗する症例に対しては手術 的治療が必要であると考える。手術方法として前方法, 後方法，前方法と後方法の併用があるが，本症例では 病巣の中心が椎体にあることより前方法を採用し, 腸 骨ならびに肋骨による固定を行い術中比較的，強固な 固定が得られたと思われたが，術後のレ線経過を見る と, instrumentation を併用した方が固定性に関しては betterであったと思われた。

\section{結語}

$\mathrm{RA}$ 病変により第 1 腰椎に高度の骨破壊をきたし観血 的治療を施行した症例を報告し若干の考察を加え報告 した.

\section{参 考 文 献}

1) Baggenstoss $\mathrm{AH}$ : Rheumatoid granulomatous nodules as destructive lesion of vertebrae. JBJS, 34-A : 601-609, 1952.

2）萩原雅也子：リウマチ病変による胸椎部脊䯣症の 1 症例. 日関外誌，5:87-94，1986.

3) Heywood AWB: Rheumatoid arthritis of the thracic and lumbar spine. JBJS, 68-B : 362-368, 1986.

4）桑原 茂：椎体にみられる RA 変化について。日関 外誌, $2: 283-288,1983$.

5）七川歓次：慢性関節りウマチにおける春椎変形。リ ウマチ病工, 永井書店, 大阪, 東京, 184, 1971.

6）菅野卓郎：椎体のリウマチについて。臨整外，13： $720-727,1978$.

質 問宮崎医科大学 田島 直也

(1) enthesis, end plate の病理的検索をされていた らお教え下さい。

(2) 本例はムチランス型だったでしょうか。

解 答国立三朝温泉病院 浪花 紳悟

(1) 椎間板周囲の組織学的所見について

$\mathrm{L}_{1}$ 上下の椎間板には, 変性を認めるも炎症の所見は なく，鞀帯に接する椎体にも炎症の所見は見られなか つた.

(2) 多数の関節の破壊を伴うムチランス型でした。

質 問産業医科大学 伊地知正光

肉芽は，椎体内発生と考えるのか，周囲関節からの 波及と考えるのか，ぞちらでしょうか。

解 答国立三朝温泉病院 浪花 紳悟

本症のリウマチ病変の部位について

椎体のリウマチ病変は 1) 滑膜関節(椎間関節） 2) entheso-peridiscal lesion 3) 椎体内の 3 つに分けられ るが, 術中所見, 組織学的所見より本症例は椎体内の リウマチ病変によるものと思われる。 